\title{
Surgical Excision Of Intraoral Lipoma; Case Report
}

\author{
Ahmed Ismail Nagy BDS, MDS, ESOI \\ Oral \& Maxillofacial Surgery Department, \\ College of Dentistry, Al-Jouf University, Saudi Arabia
}

doi: 10.19044/esj.2016.v12n12p211 URL:http://dx.doi.org/10.19044/esj.2016.v12n12p211

\begin{abstract}
Lipoma is a common tumor of soft tissue. Its location on the oral mucosa is rare, representing $1 \%$ to $5 \%$ of benign oral tumors although it is the most mesenchymal tumor of the trunk and proximal portions of extremities. Lipoma of the oral cavity may occur in any region. The buccal mucosa, tongue, and floor of the mouth are among the common locations. The clinical presentation is typically as an asymptomatic yellowish mass. The overlying epithelium is intact, and superficial blood vessels are usually evident over the tumor. Other benign connective tissue lesions such as granular cell tumor, neurofibroma, traumatic fibroma and salivary gland lesions (mucocele and mixed tumor) might be included in differential diagnosis. We present a case report of oral lipoma in the left side of the lower lip in 18 years old Saudi patient.
\end{abstract}

Keywords: Lipoma, tumor, buccal mucosa

\section{Introduction}

Lipomas are common tumors in the human body (Chidzonga MM et al., 2004; Vera JL et al., 2006), but are less frequent in the oral cavity, comprising no more than 1-5\% of all neoplasms.(Vera JL et al., 2006; Trandafir D et al., 2007; Bandeca MC et al., 2007) They commonly present as slow growing asymptomatic lesions with a characteristic yellowish color and soft, doughy feel in the buccal mucosa, floor of the mouth and tongue, in the fourth and fifth decades and generally with no gender predilection. Some studies, however, have shown a male predominance (Bandeca MC et al., 2007; Lawoyin JO et al., 2008; Adoga AA et al., 2001).

Half of oral lipomas are in the cheek and the remainders were found in the tongue, floor of the mouth, lips, palate and gingiva (Vindenes $\mathrm{H}$ et al., 1978). They are benign mesenchymal neoplasms composed of fat cells usually surrounded by a thin fibrous capsule (Frefnani ER et al., 2003). The size of tumor depends on the location but rarely exceeds $25 \mathrm{~mm}$ in diameter (Rapidis AD et al., 1982). Lipomas are usually asymptomatic until they grow 
to large size and may interfere with speaking and mastication (Chidzonga MM et al., 2004; Kesin G et al., 2002). Although malignant counterpart of this tumor, liposarcoma, is another common soft tissue neoplasm, but its occurrence in oral cavity is rare (Visscher JG, 1982).

\section{Case report}

An eighteen years old Saudi young male was referred to Dental Clinics of College of Dentistry at Al-Jouf University (Sakaka, Saudi Arabia). The patient reports that a ball in the mouth has been present approximately one year, painless and he believes that it has grown significantly in the last four months. He complaint of traumatize the tissue while eating and this ball may have become ulcerated, bleeding and with pain. While the complete medical history revealed no systemic diseases.

The intraoral examination revealed a soft nodule was covered by normal mucosa on the internal margin of the lip and the mucosa appeared without any ulceration. Appear as soft, yellowish, and the size of the lesion was approximately $2 \mathrm{~cm}$ in diameter. Hypothesis diagnosis: lipoma and fiboma (Figure 1, 2 \& 3).

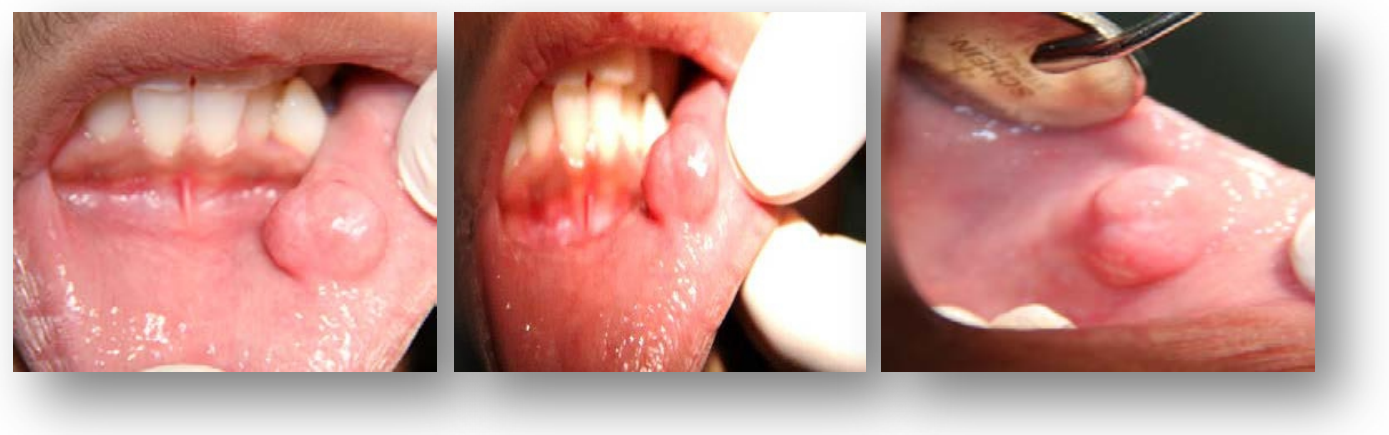

Figure 1, 2 \& 3: Soft and sessile mass in lower lip

In the pre-surgical preparation was collected all normal range of preoperative routine investigations; like complete blood count, coagulation tests and blood pressure. The patient was able to surgical excision of the lesion under local anesthesia on the dental chair.

Infiltration anesthesia around the lesion mepivacaine 3\% with vasoconstrictor (Figure $4 \& 5$ ), followed by incision with a scalpel blade $n^{0}$ 15 , giving the margin of the lesion, grasped with mosquito and tissue forceps to complete surgical resection. (Figure $6 \& 7$ ) 

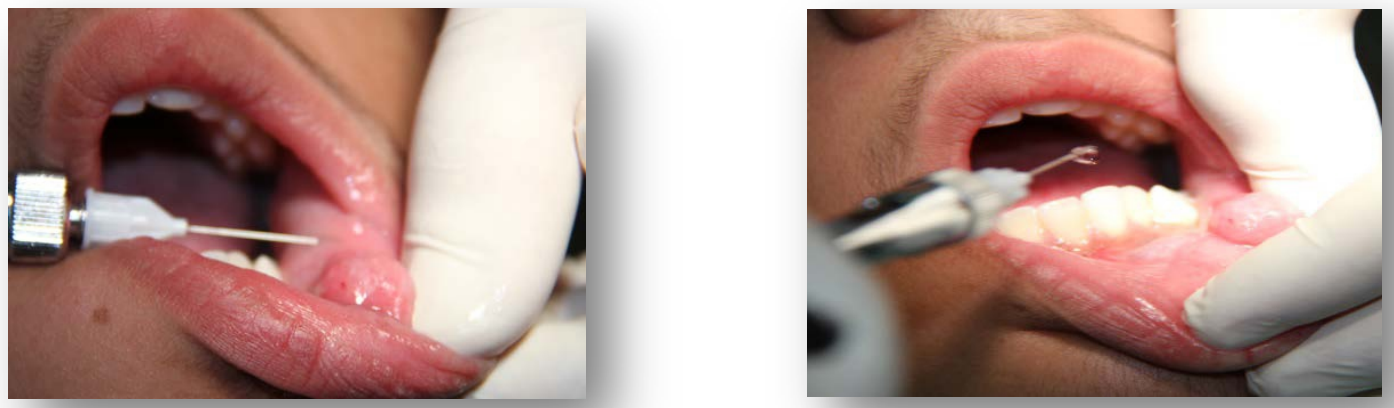

Figure 4 \& 5: Infiltration anesthesia around lesion.
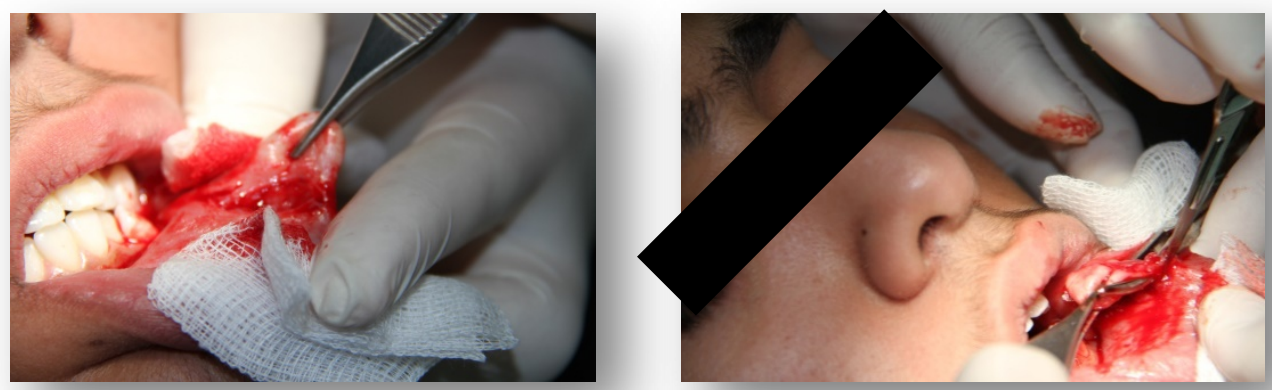

Figure 6 \& 7: Grasped with mosquito \& tissue forceps.

After removal of the lesion (Figure 8), then incision was sutured with 3-0 black silk suture (Figure 9). the piece was placed in the pot with water where it floated, showing the diagnosis of lipoma, and then the piece was transferred to the formaldehyde solution $10 \%$, and sent to pathological examination, where the material was processed and examined, confirming the diagnosis of lipoma.
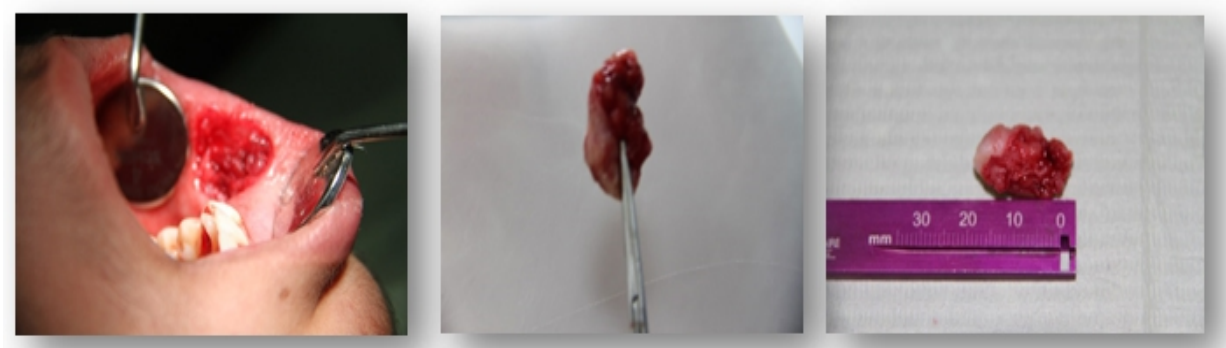

Figure 8: After removal of the lesion 

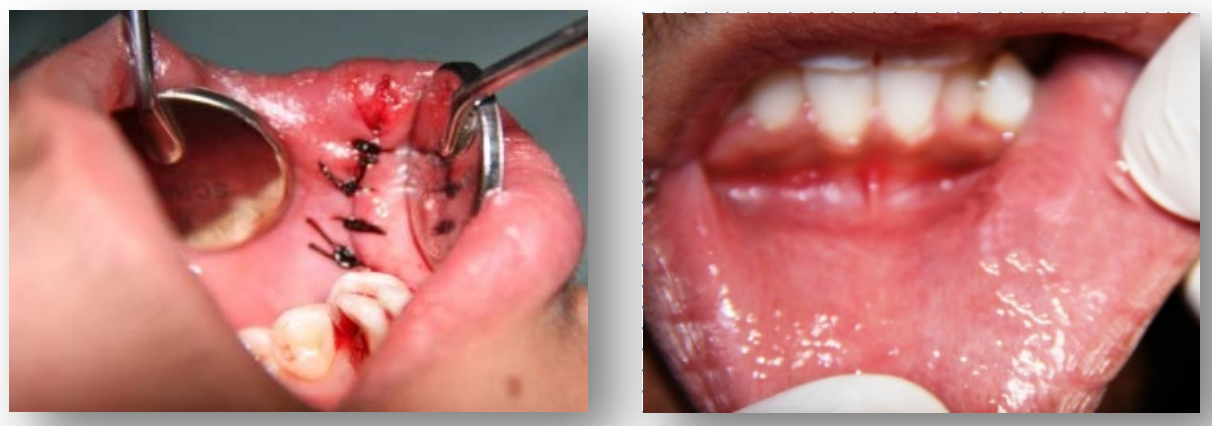

Figure 9: Suturing the incision

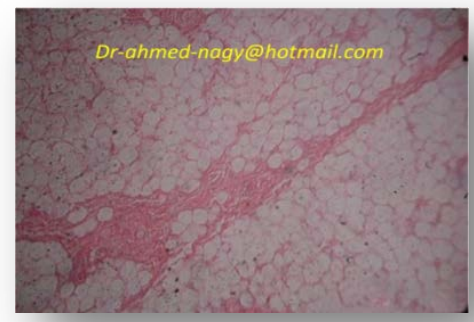

$\mathrm{F}$

Figure 10: Three months follow-up showed good healing and no evidence of recurrence.

On histologic examination (Figure 11), the tumor was composed of mature lipocytes and was well circumscribed and demonstrated a thin fibrous capsule. A distinct lobular arrangement of the cells was seen.

\section{Discussion}

Lipoma is a benign mucosa neoplasm well-know with differential diagnosis of others soft tissue pathologies. Although there is no difference in the election treatment plan which consists of complete surgical removal of the lesion with excisional biopsy (Freitas MA et al., 2009; Bandéca MC et al., 2007) and this case report occurred after the complete excision of lipoma after preoperative exams.

Lipomas are benign mesenchymal tumors that originate in mature fat cells, relatively rare in the oral cavity compared with other lesions. Generally they are well-circumscribed nodules and encapsulated and may be present in any region of oral cavity, however the buccal mucosa is the most prevalent followed by the tongue, lower lip and mouth floor (Weiss SW et al., 2009; Gnepp DR et al., 2001; Freitas MA et al., 2009). In this present case lipoma 
was in the lower lip and in many studies is the second or third most prevalent area.

Freitas et al., (2009) reviewed 26 cases of intraoral lipomas, classic lipoma was the most common in 15 cases, followed by fibrolipoma in 7 cases. In a review conducted in a Brazilian population by Fregnani et al. (2003), classic lipomas followed by fibrolipomas represent the lesions most commonly diagnosed among intraoral lipomas. However, Furlong et al. (2004) encountered a similar frequency of lesions accompanied by other benign lipomatous tumors.

The classification of these lesions establishes the following subtypes:

lipoma, fibrolipoma, intramuscular lipoma, salivary gland lipoma (Nagao T et al., 2001), spindle-cells lipoma e intraosseous lipoma11. Spindle-cell lipoma is a relatively uncommon benign lipomatous tumor, with few cases reported in literature (Kaku N et al., 2003; Said-Al-Naief et al., 2001). Said-Al-Naief et al. (2001) identified only two cases of this subtype in a revision of 164 intraoral lipomas cases, confirming the low prevalence of this subtype. Lipomas in some cases may be part of congenital alterations. An extremely rare form of intraoral lipoma was described by Mahabir et al. (2000) where the lesion was found associated with congenital cleft palate. Another case of congenital lesion was described by Perri de Carvalho et al. (1987) of a 7 years-old boy in the region of upper labial frenum, in this case the treatment eliminated the habited of sucking the lesion and eventually resulted in adjacent teeth eruption.

The histopathological features are a tumor composed of adipose tissue involved well differentiated connective tissue capsule. Although morphologically cannot be differentiated from normal fat cells, lipoma cells have faster metabolism. Sometimes the capsule may be missing or broken (Epivatianos A et al., 2000). When the connective tissue is a significant part of the lesion begun to be fibrolipoma (Gnepp DR, 2009; Weiss SW et al., 2001; Fregnani ER et al., 2003).

\section{Conclusion}

Intraoral lipoma was a benign neoplasm with low prevalence in the oral cavity; clinicians must be able to recognize differential diagnosis and the correct treatment, surgical excision, to ensure the comfort, welfare and quality of life of patients.

Surgical excision is the main treatment. Recurrence is reduced by wide surgical excision (Vera JL et al., 2006). Infiltrating lipomas are difficult to extirpate and are liable to recurrence (Chidzonga MM et al., 2004; Adoga AA et al., 2001). 


\section{References:}

Chidzonga MM, Mahomva L, Marimo C (2006). Gigantic tongue lipoma: a case report. Med Oral Patol Oral Cir Bucal. 11(5):E437-9.

Del Castillo Pardo de Vera JL, Cebrian Carretero JL, Gomez GE (2004). Chronic lingual ulceration caused by lipoma of the oral cavity. Case report. Med Oral. 9(2):166.

Trandafir D, Gogalniceanu D, Trandafir V, Caruntu ID (2007). Lipomas of the oral cavity-a retrospective study. Rev Med Chir Soc Med Nat Iasi. 111(3):754-8.

Bandeca MC, de Padua JM, Nadalin MR, Ozorio JE, Silva-Sousa YT, Cruz Perez DE (2007). Oral soft tissue lipomas: a case series. J Can Dent Assoc. 73(5):431-4.

Adoga AA, Nimkur TL, Manasseh AN, Echejoh GO (2008). Buccal soft tissue lipoma in an adult Nigerian: a case report and literature review. J Med Case Reports. 2: 382.

Lawoyin JO, Akande OO, Kolude B, Agbaje JO (2001). Lipoma of the oral cavity: clinicopathological review of seven cases from Ibadan. Niger $\mathrm{J}$ Med. 10(4):189-91.

Vindenes H (1978). Lipomas of the oral cavity. Int J Oral Surg. 7(3):162-6. Fregnani ER, Pires FR, Falzoni R, Lopes MA, Vargas PA (2003). Lipomas of the oral cavity: clinical findings, histological classification and proliferative activity of 46 cases. Int J Oral Maxillofac Surg. 32(1):49-53. Rapidis AD (1982). Lipoma of the oral cavity. Int J Oral Surg. 11(1):30-5. Keskin G, Ustundag E, Ercin C (2002). Multiple infiltrating lipomas of the tongue. J Laryngol Otol. 116(5):395-7.

Visscher JG (1982). Lipomas and fibrolipomas of the oral cavity. J Oral Maxillofac Surg. 10:177-81.

Gnepp DR (2009), editor. Diagnostic surgical pathology of the head and neck. 2nd ed. Philadelphia: Saunders.

Weiss SW, Goldblum JR (2001). Benign lipomatous tumors. In:Weiss SW, Goldblum JR, Enzinger FM. Enzinger andWeiss's soft tissue tumors. 4th ed. St Louis: Mosby. p.571-639.

Fregnani ER, Pires FR, Falzoni R, Lopes MA,Vargas PA. Lipomas of the oral cavity: clinical findings, histological classification and proliferative activity of 46 cases. Int J Oral Maxillofac Surg. 2003; 32(1): 49-53.

Aust MC, Spies M, Kall S, Gohritz A, Boorboor P, Kolokythas P et al (2007). Lipoma after blunt soft tissue trauma: are they real? Analysis of 31 cases. Br J Dermatol. 157:92-9.

Freitas MA, FreitasVS, Lima AAS, Pereira Jr. FB (2009). Intraoral lipomas: a study of 26 cases in a Brazilian population. Quintessence Int. 40(1):79-85. 
Pass B, Guttenberg S, Childers EL, Emery RW (2006). Soft tissue lipoma with the radiographic appearance of a neoplasm within the mandibular canal. Dentomaxillofac Radiol. 35:299-302.

Bandéca MC, Pádua JM, Nadalin MR, Ozóris JE, Silva Sousa YT, Cruz Perez DE (2007). Oral soft tissue lipomas: a case series. J Can Dent Assoc. 73(5):431-4.

Furlong MA, Fanburg-Smith JC, Childers ELB (2004). Lipoma of the oral and maxillofacial region: site and subclassification of 125 cases. Oral Surg Oral Med Oral Pathol Oral Radiol Endod. 98:441-50.

Nagao T, Sugano I, Ishida Y, Asoh A, Munakata S, Yamazaki K et al (2001). Sialolipoma: a report of seven cases of a new variant of salivary gland lipoma. Histopathology. 38(1):30-6.

Buric N, Krasic D, Visnjic M, Katic V (2001). Intraoseous mandibular lipoma: a case report and review of the literature. J Oral Maxillofac Surg. 59:1367-71.

Kaku N, Kashima K, Daa T, Nakayaa I, Kerakawarichi H, Hashimoto H et al (2003). Multiple spindle cell lipomas of the tongue: report of a case. APMIS. 111(5):581-5.

Said-Al-Naief N, Zahurullah FR, Sciubba J (2001). Oral spindle cell lipoma. Ann Diagn Pathol. 5:207-15.

Mahabir RC, Mohammad JA, Courtmanche DJ (2000). Lipoma of the cleft soft palate: a case report of a rare congenital anomaly. Cleft Palate Craniofac J. 37(5):503-5.

Perri de Carvalho AC, Martinelli C, Sanches MG (1987). Congenital lipoma in the oral cavity. A case report. Quintessence Int. 18(11):799-802.

Epivatianos A, Markopoulos AK, Papanayotou P (2000). Benign tumors of adipose tissue of the oral cavity: a clinicopathologic study of 13 cases. J Oral Maxillofac Surg. 58(10):1113-7. 